\title{
The Effectiveness of Cytoreductive Surgery and Hyperthermic Intraperitoneal Chemotherapy (HIPEC) in Patients with Malignant Peritoneal Mesothelioma: A Tertiary Center Experience
}

\author{
Bulent AKSEL ${ }^{1}$, Hanifi SAHIN ${ }^{2}$, Mustafa E. SARI ${ }^{2}$ \\ ${ }^{1}$ University of Health Sciences, Faculty of Medicine, Dr. Abdurrahman Yurtsalan Training and Research Hospital, \\ Department of General Surgery \\ ${ }^{2}$ University of Health Sciences, Faculty of Medicine, Zekai Tahir Burak Women's Health Training and Research Hospital, \\ Department of Gynecologic Oncology, Ankara, TURKEY
}

\begin{abstract}
In this study, we aimed to investigate the effect of cytoreductive surgery (CRS) and hyperthermic intraperitoneal chemotherapy (HIPEC) procedures on overall survival (OS), morbidity, and mortality rates in patients with malignant peritoneal mesothelioma (MPM), an extremely rare tumor. Between January 2012 and March 2017, 21 patients who were diagnosed with a MPM and underwent CRS plus HIPEC were retrospectively analyzed. The median age was 60 (range, 18 to 80 ) years. Eighteen patients (76.2\%) had a history of exposure to asbestos. The median follow-up was 17 months (range, 1 to 36 months). The median OS was 26 months. The rates of OS at 12,24 , and 36 months were $80 \%, 80 \%$, and $40.5 \%$, respectively. The perioperative mortality and morbidity rates were $4.8 \%$ and $33.3 \%$, respectively. The 3-year survival rate was $93.8 \%$ for patients treated with a CC 0 or 1 resection, whereas the median OS was 6 months for those treated with a CC 2 or 3 resection ( $p=0.007$ ). Age, gender, smoking status, asbestos exposure, pathological type, peritoneal cancer index (PCI), lymph node involvement, ascites, and cancer antigen (CA)-125 were not found to significantly influence the OS in univariate analysis ( $p>0.05$ ). A successful CRS plus HIPEC in selected patients with MPM seems to have beneficial effects on OS. In addition, our morbidity and mortality rates are consistent with the current literature.
\end{abstract}

Keywords: Malignant mesothelioma, Cytoreductive surgery, Hyperthermic intraperitoneal chemotherapy, Survival, Mortality

ÖZET

Malign Peritoneal Mezotelyoma Hastalarında Sitoredüktif Cerrahi ve Hipertermik İntraperitoneal Kemoterapi (HIPEC) Etkinliği: Tersiyer Bir Merkez Deneyimi

Bu çalışmada oldukça nadir görülen bir tümör olan malign peritoneal mezotelyoma olgularında sitoredüksiyon cerrahisi ve hipertermik intraperitoneal kemoterapinin (HIPEC) genel sağkalım (OS), morbidite ve mortalite oranları üzerindeki etkisi araştıııdı. Bu çalışmada Ocak 2012 - Mart 2017 tarihleri arasında malign mezotelyoma tanısı konulan ve akabinde sitoredüksiyon cerrahisi ve HIPEC tedavisi uygulanan 21 olgu retrospektif olarak incelendi. Hastaların ortanca yaşı 60 (18-80) yıl idi. On sekiz hastada (\%76.2) asbeste maruz kalma öyküsü vardı. Ortanca takip süresi 17 (1-36) ay olarak bulundu. Ortanca OS süresi 26 aydı. 12, 24 ve 36. aylardaki OS oranları sırasıyla \%80, \%80 ve \%40.5 olarak saptandı. Perioperatif mortalite ve morbidite oranları sırasıyla \%4.8 ve \%33,3 idi. Sitoredüksiyon skoru (CC) 0 veya 1 olan hastalarda 3 ylllık OS oranı \%93.8 iken, CC 2 veya 3 olanlarda ortanca OS 6 ay olarak tespit edildi ( $p=0.007)$. Tek değişkenli analizde yaş, cinsiyet, sigara içme durumu, asbeste maruz kalma, patolojik tip, Peritoneal Kanser İndeksi (PCl) skoru, lenf nodu tutulumu, asit ve kanser antijen (CA)-125'in OS'yi anlamlı derecede etkilemediği bulundu ( $\mathrm{p}>0.05$ ). Malign peritoneal mezotelyoma olgularında başarılı bir sitoredüksiyon cerrahisi ve HIPEC tedavisi, sağkalım üzerinde olumlu bir etkiye sahiptir. Morbidite ve mortalite oranlarımız literatür ile uyumludur.

Anahtar Kelimeler: Malign mezotelyoma, Sitoredüktif cerrahi, Hipertermik intraperitoneal kemoterapi, Sağkalım, Mortalite 


\section{INTRODUCTION}

First described in 1908, malignant peritoneal mesothelioma (MPM) is a rare and ultimately fatal neoplasm that arises from mesothelial cells lining the peritoneum. ${ }^{1}$ Currently, MPM accounts for 25 to $33 \%$ of all mesotheliomas, and the pleura is the most common site of origin. ${ }^{2,3}$ The incidence of MPM is estimated to be between 400 and 800 cases annually, with both males and females having an equal incidence of the disease., ${ }^{4,5}$

The association between malignant mesothelioma (MM) and asbestos exposure has been shown in multiple studies. ${ }^{6-8}$ Although both are asbestosinduced cancers, the incidence of pleural MM is significantly higher (85\%) than that of peritoneal MM (15\%). It has been proposed that carcinogenesis is a result of asbestos-induced inflammation; however, it is not clear what contributes to the differences observed between incidences of these two cancers. ${ }^{9}$ Patients with MPM most commonly present with abdominal pain, increasing abdominal girth, weight loss, and abdominal masses, with or without ascites. ${ }^{10}$

The cytological and histological features of MPM have been described in recent studies. ${ }^{11,12}$ Three broad pathological subtypes of MPM have been described, namely epithelioid, mixed/biphasic, and sarcomatoid. ${ }^{13,14}$ Epithelioid MPM is by far the most commonly found subtype; it is diagnosed in approximately $75-92 \%$ of cases, while the mixed/ biphasic type comprises $8-22 \%$ of cases. ${ }^{13}$ This distinction is important, as biphasic and sarcomatoid MPMs are extremely resistant to treatment and are associated with poor prognosis. ${ }^{15}$

MPM should be considered in the diagnosis in patients with a diffuse malign process in the abdomen on initial clinical evaluation. It is confirmed based on suspicion of findings on cross-sectional imaging and tissue biopsy with appropriate immunohistochemical staining. Computed tomography (CT) scanning is the imaging modality most commonly used. ${ }^{16}$ Magnetic resonance imaging and positron emission tomography provide little additional information, and their roles in evaluating MPM remain unclear. ${ }^{17,18}$ In addition to imaging elevated cancer antigen (CA)-125; however, this marker alone is not tumor specific, and it is typically best used to monitor for disease recurrence or progression in those with a confirmed diagnosis. ${ }^{19}$ The currently accepted approach for initial MPM treatment is cytoreductive surgery (CRS) and regional chemotherapy treatment strategies.

The aim of this study was to evaluate the survival outcomes and to calculate the morbidity and mortality rates in patients who underwent primary CRS and HIPEC.

\section{PATIENTS AND METHODS}

We analyzed 21 consecutive patients with MPM who underwent CRS with HIPEC between January 2012 and March 2017 from a retrospective database in our tertiary center. The ethics committee of the hospital approved the study. A written informed consent was obtained from each patient. The study was conducted in accordance with the principles of the Declaration of Helsinki. Data on age, sex, asbestos exposure, smoking status, pathological findings, serum CA-125 levels, cytoreduction score (CC), peritoneal cancer index (PCI), perioperative complications, length of hospitalization, recurrence, and follow up of patients were recorded from the database.

The inclusion criteria were as follows: no sign of distant metastasis on CT imaging of the abdomen and chest and sufficient cardiorespiratory and renal function to allow the required resection. Benign multicystic mesothelioma and well-differentiated papillary peritoneal mesothelioma histopathological types were excluded, as well as cases with Eastern Cooperative Oncology Group (ECOG) performance status $>2 .^{20}$

The PCI was determined prospectively at the time of abdominal exploration. The PCI was an assessment of the distribution and extent of MPM in 13 abdominopelvic regions recorded by the surgeon at the time of abdominal exploration. ${ }^{21}$ It is scored according to the size of the tumoral nodules, as follows: lesion size (LS)-0: no tumor; LS-1: tumor nodule $\leq 0.5 \mathrm{~cm}$; LS-2: tumor nodule of $0.5-5 \mathrm{~cm}$; and LS-3: tumor nodule $>5 \mathrm{~cm}$. The maximum score is 39. Patients were divided into two groups by their PCI scores; one group had PCI scores less than 20, and the other had scores greater than 20 . 
Table 1. Demographic and clinicopathological characteristics of all patients $(n=21)$

\begin{tabular}{|c|c|}
\hline Characteristics & Values, n (\%) \\
\hline Age (year) median & $60(18-80)$ \\
\hline$<60$ & $10(47.6 \%)$ \\
\hline$\geq 60$ & $11(52.4 \%)$ \\
\hline \multicolumn{2}{|l|}{ Sex } \\
\hline Male & $13(61.9 \%)$ \\
\hline Female & $8(38.1 \%)$ \\
\hline Asbestos exposure & $16(76.2 \%)$ \\
\hline Smoking & 7 (33.3 \%) \\
\hline \multicolumn{2}{|l|}{ Pathological type } \\
\hline Epithelioid & $18(85.7$ \%) \\
\hline Biphasic & $3(14.3 \%)$ \\
\hline \multicolumn{2}{|l|}{ Symptoms } \\
\hline Abdominal distention & $11(61.4 \%)$ \\
\hline Abdominal pain & 5 (23.8 \%) \\
\hline Loss of weight & $3(14.3 \%)$ \\
\hline lleus & $2(9.5 \%)$ \\
\hline \multicolumn{2}{|l|}{ Ascites } \\
\hline Yes & $13(61.9 \%)$ \\
\hline No & $8(38.1 \%)$ \\
\hline \multicolumn{2}{|l|}{ Lymph node Involvement } \\
\hline Yes & $5(23.8 \%)$ \\
\hline No & $16(76.2 \%)$ \\
\hline Serum Ca-125 (median, IU/ml) & $53.3(2.9-2390)$ \\
\hline$\geq 35$ & $13(61.9 \%)$ \\
\hline$<35$ & 8 (38.1%) \\
\hline \multicolumn{2}{|l|}{$\mathrm{CC}$} \\
\hline CC 0 or 1 & $16(76.2 \%)$ \\
\hline CC 2 or 3 & $5(23.8 \%)$ \\
\hline PCI (median, range) & $21(8-39)$ \\
\hline$<20$ & $9(42.9 \%)$ \\
\hline$\geq 20$ & $12(57.1 \%)$ \\
\hline Perioperative mortality & $1(4.8 \%)$ \\
\hline Perioperative morbidity & 7 (33.3 \%) \\
\hline Grade 1-2 & 2 (9.5 \%) \\
\hline Grade 3-4-5 & 5 (23.8 \%) \\
\hline \multicolumn{2}{|l|}{ Type of complication } \\
\hline Enterocutaneous fistula & $1(4.8 \%)$ \\
\hline Anastomotic leak & $3(14.3 \%)$ \\
\hline Hematologic & $1(4.8 \%)$ \\
\hline Renal insufficiency (not require dialysis) & $2(9.5 \%)$ \\
\hline \multicolumn{2}{|l|}{ Status } \\
\hline Death & $5(23.8 \%)$ \\
\hline Alive & $16(76.2 \%)$ \\
\hline Cause of death & $5(23.8 \%)$ \\
\hline Surgical complication & $1(4.8 \%)$ \\
\hline With disease & $4(19 \%)$ \\
\hline
\end{tabular}

Completeness of cytoreduction was classified according to Sugarbaker's criteria. ${ }^{21}$ The $\mathrm{CC}$ was determined for all patients by the surgeon at the com- pletion of the CRS procedure, as follows: a CC of 0 indicated no visible evidence of disease; a CC of 1 indicated tumor nodules less than $2.5 \mathrm{~mm}$ in diameter, without a confluence of disease at any site; a CC of 2 indicated tumor nodules between $2.5 \mathrm{~mm}$ and $2.5 \mathrm{~cm}$ in the absence of a contiguous layer of disease at any anatomic site in the abdomen or pelvis; and a CC of 3 indicated tumor nodules greater than $2.5 \mathrm{~cm}$ in diameter or a confluence of disease layered out at any site within the abdomen or pelvis. Morbidity and toxicity associated with the combined procedure was classified according to the National Cancer Institute, Common Terminology Criteria for Adverse Events version 3 (NCI, CTCAEv3) criteria as follows: G1, mild; G2, moderate; G3, severe; G4, life-threatening or disabling; and G5, death. ${ }^{22}$ All procedures were performed by the same surgical oncological team with extensive experience in regional therapies. The CRS also includes stripping the whole parietal peritoneum, resecting the visceral peritoneum and tumor-involved intestinal tract. Cholecystectomy, Liver Segment Resection, partial gastrectomy, splenectomy, rectectomy, hysterectomy and bilateral salpingo-oophorectomy are all necessary if tumor implants are observed in the gallbladder fossa, spleen fossa and Douglas cavity.Perfusion was performed with a closed technique, using a hyperthermia pump (Belmont ${ }^{\circledR}$ Hyperthermia Pump HIPEC, Massachusetts, USA). The peritoneal perfusate, consisting of $4000 \mathrm{cc}$ of $\mathrm{NaCl}(0.9 \%)$, was warmed to $42^{\circ} \mathrm{C}$ and infused into the abdomen at $1.000 \mathrm{cc} /$ min for 90 min with a combination of mitomycin $\mathrm{C}$ and cisplatin. The drugs doses were $3.3 \mathrm{mg} / \mathrm{m}^{2} / \mathrm{L}$ for $\mathrm{MMC}$ and $50 \mathrm{mg} / \mathrm{m}^{2} / \mathrm{L}$ for cisplatin. Chemotherapeutic agents were dissolved in $\mathrm{NaCl}(0.9 \%)$ and added to the perfusate after the perfusion fluid had reached $42^{\circ} \mathrm{C}$ (about $5 \mathrm{~min}$ ). After the HIPEC procedure was finished, all catheters and temperature probes were removed. The standard primary chemotherapy regimen included pemetrexed 500 $\mathrm{mg} / \mathrm{m}^{2}$ plus cisplatin $75 \mathrm{mg} / \mathrm{m}^{2}$ every 21 days for 6 cycles was given as adjuvant chemotherapy.

Overall survival (OS) was calculated as the time period between primary surgery to the date of death or the last follow-up. Patients who were survivors at the time of their last visit were censored. 
Table 2. Univariate analysis of survival of 21 patients with malignant peritoneal mesotheliolma

\begin{tabular}{|c|c|c|}
\hline Variable & $\begin{array}{l}\text { Median survival } \\
\text { (month) }\end{array}$ & $\mathbf{p}$ \\
\hline Age & NR & 0.16 \\
\hline \multicolumn{3}{|l|}{$<60$} \\
\hline$\geq 60$ & 26 & \\
\hline \multicolumn{3}{|l|}{ Sex } \\
\hline Male & NR & 0.55 \\
\hline Female & 14.4 & \\
\hline \multicolumn{3}{|l|}{ Asbestos exposure } \\
\hline Yes & NR & 0.23 \\
\hline No & NR & \\
\hline \multicolumn{3}{|l|}{ Pathologic type } \\
\hline Epithelioid & 26 & 0.51 \\
\hline Biphasic & NR & \\
\hline \multicolumn{3}{|l|}{ Smoking } \\
\hline Yes & NR & 0.65 \\
\hline No & 26 & \\
\hline \multicolumn{3}{|l|}{$\mathrm{CC}$} \\
\hline Complete (CC 0 or 1$)$ & NR & $0.007^{\star}$ \\
\hline Incomplete(CC 2 or 3) & 6 & \\
\hline \multicolumn{3}{|l|}{ Ascites } \\
\hline Yes & 26 & 0.36 \\
\hline No & NR & \\
\hline \multicolumn{3}{|l|}{ Lymph node involvement } \\
\hline Yes & NR & 0.60 \\
\hline No & 26 & \\
\hline \multicolumn{3}{|l|}{ Serum Ca-125 (IU/ml) } \\
\hline$<35$ & NR & 0.09 \\
\hline$\geq 35$ & 26 & \\
\hline \multicolumn{3}{|l|}{$\mathrm{PCl}$} \\
\hline$<20$ & 26 & 0.13 \\
\hline$\geq 20$ & NR & \\
\hline
\end{tabular}

MPM= Malignant peritoneal mesothelioma; NR= Not reached median yet; $\mathrm{CC}=$ Cytoreduction Score; $\mathrm{PCl}=$ Peritoneal Cancer Index

The postoperative follow up included physical examination, thoracic/abdominal $\mathrm{CT}$ scan and marker measurements every 3 months during the first 2 years. These assessments were then repeated every 6 months for 3 years and annually thereafter. Recurrent disease or progression was confirmed pathologically.

\section{Statistical Analysis}

Statistical analysis was performed using the statistical software package SPSS version 22.0 (IBM Corp., Armonk, NY, USA). The data were ex- pressed as median and range for continuous variables. Binary variables were reported as counts and percentages. The Kaplan-Meier test was used to identify differences between curves. Survival was measured from the time of diagnosis. A p value of less than 0.05 was considered statistically significant.

\section{RESULTS}

The median age of the patients was 60 years (range, $18-80$ years). There were 13 (61.9\%) men and 8 (38.1\%) women included in this study. Baseline demographic and clinicopathological characteristics of the patients are shown in Table 1.

Peritoneal mesothelioma presented as abdominal distention in 11, abdominal pain in 5, loss of weight in 3 , and ileus in 2 patients. Fourteen patients were diagnosed by laparoscopy or laparotomy, and 7 patients by cytology or needle biopsy. Preoperative histopathological results were confirmed with the final pathology. Diagnosis of mesothelioma was confirmed in every patient via a review of pertinent immunohistochemical studies. A total of 18 patients $(85.7 \%)$ exhibited the epithelial histological subtype, while 3 of $21(14.3 \%)$ exhibited the biphasic subtype.

The median follow-up period was 17 months (range, 1-36 months). The median OS was 26 months (standard error [SE]: 14.3, 95\% confidence interval [CI]: 0 - 54.02) (Figure 1). The OS rates at 12,24 , and 36 months were $80 \%, 80 \%$, and $40.5 \%$ respectively. The median PCI was 21 (range, 8-39). The median duration of the operation was $240 \mathrm{~min}$ (range, 180-420 min). Finally, the median length of hospitalization was 18 days (range, 5-23 days).

All patients' ECOG performances were scored as 0 or 1 . The numbers of patients with perioperative mortality and morbidity are $1(4.8 \%)$ and 7 (33.3\%), respectively. The grade 1-2 and grade 3-5 morbidity rates were $9.5 \%$ ( 2 patients) and $33.3 \%$ (7 patients), respectively.

There was one mortality due to complications on Day 25 postoperatively. The patient suffered from enterocutaneous fistulas and related complications, and eventually died of cardiac arrest. Other complications are presented in Table 1. After the surgi- 


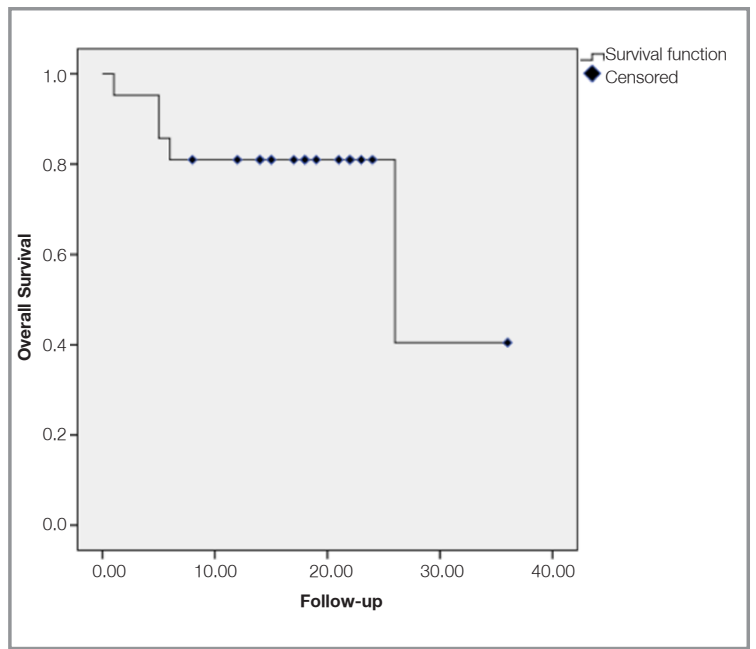

Figure 1. Overall survival of 21 patients with malignant peritoneal mesothelioma according to the Kaplan-Meier method

cal procedure, 16 patients were considered to have a CC 0 or CC 1 resection, and 5 had a CC2 or CC 3 resection. The 3-year survival rate was $93.8 \%$ for patients treated with a $\mathrm{CC} 0$ or $\mathrm{CC} 1$ resection, whereas the median survival was 6 months for those treated with a CC 2 or $\mathrm{CC} 3$ resection (Figure 2). Age, sex, smoking status, asbestos exposure, pathological type, PCI, lymph node involvement, ascites, and CA-125 were not found to significantly influence the OS in univariate analysis $(\mathrm{p}>0.05)$ (Table 2).

\section{DISCUSSION}

MPM is considered as a fatal condition. Systemic chemotherapy and surgery have shown limited benefit in this entity. ${ }^{23} \mathrm{CRS}$ with HIPEC showed a clear improvement in the outcome of MPM compared to traditional systemic chemotherapy. ${ }^{24-26}$

We evaluated the short-term results of 21 cases and sought to report the preliminary findings of the study. The limitations of this study were the small sample size, short follow-up period, and retrospective design. The median follow up was 17 months, and the median OS was 26 months. The perioperative mortality and morbidity rates were $4.8 \%$ and $33.3 \%$, respectively. Sixteen patients underwent complete cytoreduction (CRS-S 0 and 1 ) and 5 patients underwent incomplete cytoreduction surgery

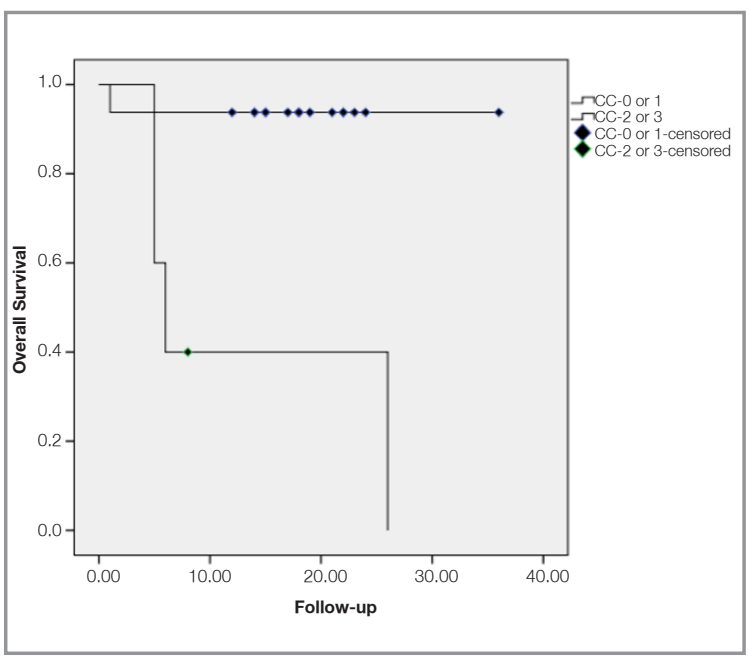

Figure 2. Survival of 21 patients with malignant peritoneal mesothelioma according to the completeness of cytoreductive surgery

(CC 2 and 3). In cases with CC 2 and 3, the median OS was 6 months.

Similar results have been found in many studies with short and long follow-up periods. The earliest study for this combined treatment (CRS+HIPEC) revealed that the median survival of 33 patients was 31 months, with 12-, 36-, and 60-month survival rates of $77 \%, 56 \%$, and $47 \%$, respectively. The most significant positive predictive factors of survival were female sex, low prior surgical score, completeness of cytoreduction and second-look surgery. The morbidity rate for this combined treatment was $33 \%$, and the perioperative mortality rate was $3 \% .27$

A phase II study including 49 patients showed that the median survival was an encouraging 92 months, and the 1-, 2-, 3-, and 5-year survival rates were $86 \%, 77 \%, 59 \%$, and $59 \%$. The morbidity rate for this combined treatment was $25 \%$, and no perioperative mortality was observed. In addition, factors associated with improved OS were history of previous debulking surgery, absence of deep tissue invasion, minimal residual disease after surgical resection, and age younger than 60 years. ${ }^{28}$ In another observational study including 20 patients with peritoneal mesothelioma treated with CRS and HIPEC, the median survival was 29.5 months, with 1- and 3-year survival rates of $78.2 \%$ and $46.3 \%$, respectively. Survival was found to be in- 
fluenced by completeness of cytoreduction and histological subtype. ${ }^{25}$

A multi-institutional registry study evaluated CRS combined with HIPEC for diffuse, malignant, peritoneal mesothelioma. Among 401 patients enrolled, 187 (46\%) had complete or near-complete cytoreduction, and $372(92 \%)$ received HIPEC. Of the HIPEC patients, $311(83 \%)$ received cisplatin and doxorubicin. The median follow-up period was 33 months. The median OS was 53 months (1235 months), and the 3- and 5-year survival rates were $60 \%$ and $47 \%$, respectively. Four prognostic factors that were independently and significantly associated with improved survival in a multivariate analysis were epithelial subtype, absence of lymph node metastasis, completeness of cytoreduction, and use of HIPEC. In addition, perioperative mortality and morbidity rates were found to be $2 \%$ and $46 \%$ in this study. ${ }^{29} \mathrm{~A}$ second multi-institutional report that included 211 patients treated at three centers showed an OS of 38 months and 5- and 10-year survival rates of $41 \%$ and $26 \%$, respectively. All patients underwent CRS and HIPEC using either cisplatin or MMC. Factors independently associated with improved survival in the study included a CC of 0 or 1 and the histological grade of the tumor. In this study, the use of cisplatin versus mitomycin $\mathrm{C}$ during HIPEC was associated with improved survival; interestingly, the benefit was most marked in those who had a CC of 0 or 1 , and there was no benefit to HIPEC with either agent in patients who had a suboptimal surgical cytoreduction $(\mathrm{CC} \geq 2)$. In addition, the perioperative mortality and morbidity rates were found to be $2.3 \%$ and $39.4 \%$ in this study. ${ }^{30}$ Both multicenter articles support our study results in terms of complete cytoreduction, morbidity, and mortality rates.

Two recent population-based studies have been reported on the use of surgical intervention in patients with MPM. In an analysis of 1.591 patients diagnosed with MPM between 1973 and 2010 obtained from the Surveillance, Epidemiology, and End Results database, several parameters associated with increased risk of shortened survival were identified, including advancing age, male sex, histology (biphasic versus epithelioid), and extent of disease. ${ }^{31}$ The study also found that surgical resection was associated with improved OS, that sur- vival after surgical resection improved over time, and that currently, almost $57 \%$ of individuals with a diagnosis of MPM do not undergo any type of surgical resection. Together, the data suggest that over time, improvement in patient selection has resulted in better outcomes after surgical resection, but many individuals who may be good candidates for surgical resection are not presented with that option. $^{31}$

A meta-analysis of 20 publications reporting on 1,047 patients with MPM undergoing CRS and HIPEC found a complete or near-complete cytoreduction (CC 0 or 1$)$ in $67 \%$ of patients. ${ }^{32}$ The estimated 5-year survival in the cohort was $42 \%$; treatment factors associated with improved survival included the use of early postoperative intraperitoneal chemotherapy (EPIC) and the use of cisplatin alone or in combination during HIPEC or EPIC. ${ }^{32}$ These two population studies also support our study concerning the effectiveness of complete CRS.

Occupational and environmental asbestos exposure remains a public health problem around the world. In some rural areas of Turkey, MM is endemic due to environmental exposure from asbestos-contaminated soil. ${ }^{33}$ Some genetic studies of Turkish families living in these remote villages in Turkey suggest that some individuals may also possess a genetic predisposition to developing mesothelioma. ${ }^{34}$ Researchers have reported that asbestos exposure has a negative effect on survival. ${ }^{35}$ In our study, 18 patients $(76.2 \%)$ had been exposed to asbestos. However, asbestos exposure did not seem to significantly influence survival in a univariate analysis.

The initial diagnosis of MPM may be difficult, and the definitive identification of the disease process may be delayed by months or even a year.10 The index of suspicion for such a rare condition is low, and the symptoms and signs are nonspecific. An abdominal and pelvic CT is usually necessary to clarify the need for paracentesis with cytology, laparoscopy, and laparotomy with biopsy. In our study, thoracic and abdominal CT imaging was performed in all cases. Fourteen patients were diagnosed by laparoscopy/laparotomy, while seven were diagnosed by cytology/needle biopsy. 
The preoperative histopathological results were confirmed with the final pathology. CRS with HIPEC can be considered a standard of care for patients with MPM if optimal cytoreduction can be achieved. In addition, the effect of new systemic cytotoxic agents, such as pemetrexed, prior to surgery is gaining attention in the treatment of peritoneal mesothelioma. ${ }^{36,37}$ If immediate surgery and intraperitoneal chemotherapy are not suitable for patients, they may be potential candidates for systemic chemotherapy with these new agents prior to surgery. ${ }^{38,39}$

\section{Conclusion}

In conclusion, MPM is a fatal disease. An effective CRS seems to be a positive factor for OS, as survival for incomplete surgery cases is 6 months. The postoperative mortality and morbidity rates in this study were compatible with those reported in the literature. We detected asbestos exposure as $76 \%$ in our study. CRS plus HIPEC represent a promising strategy for treating selected patients with MPM.

\section{REFERENCES}

1. Bridda A, Padoan I, Mencarelli R, et al. Peritoneal mesothelioma: a review. Med Gen Med 9: 32, 2007.

2. Peto J, Decarli A, La Vecchia C, et al. The European mesothelioma epidemic. BJC 79: 666-672, 1999.

3. Antman K, Hassan R, Eisner M, et al. Update on malignant mesothelioma. Oncology (Williston Park) 19: 1301-1309, 2005.

4. Price B, Ware A. Time trend of mesothelioma incidence in the United States and projection of future cases: an update based on SEER data for 1973 through 2005. Crit Rev Toxicol 39: 576-588, 2009.

5. Larson T, Melnikova N, Davis SI, et al. Incidence and descriptive epidemiology of mesothelioma in the United States, 1999-2002. Int J Occup Environ Med 13: 398-403, 2007.

6. Spirtas R, Heineman EF, Bernstein L, et al. Malignant mesothelioma: attributable risk of asbestos exposure. J Occup Environ Med 51: 804-811, 1994.

7. Boffetta P. Epidemiology of peritoneal mesothelioma: a review. Ann Oncol 18: 985-990, 2007.

8. Kraynie A, de Ridder GG, Sporn TA, et al. Malignant mesothelioma not related to asbestos exposure: Analytical scanning electron microscopic analysis of 83 cases and compari- son with 442 asbestos-related cases. Ultrastruct Pathol 40: 142-146, 2016.

9. Dragon J, Thompson J, MacPherson M, et al. Differential Susceptibility of Human Pleural and Peritoneal Mesothelial Cells to Asbestos Exposure. J Cell Biochem 116: 1540-1552, 2015.

10. Acherman YI, Welch LS, Bromley CM, et al. Clinical presentation of peritoneal mesothelioma. Tumori 89: 269-273, 2003.

11. Patel NP, Taylor CA, Levine EA, et al. Cytomorphologic features of primary peritoneal mesothelioma in effusion, washing, and fine-needle aspiration biopsy specimens: examination of 49 cases at one institution, including post-intraperitoneal hyperthermic chemotherapy findings. Am J Clin Pathol 128: 414-422, 2007.

12. Husain AN, Colby TV, Ordonez NG, et al. Guidelines for pathologic diagnosis of malignant mesothelioma: a consensus statement from the International Mesothelioma Interest Group. Arch Pathol Lab Med 133: 1317-1331, 2009.

13. Cerruto CA, Brun EA, Chang D, et al. Prognostic significance of histomorphologic parameters in diffuse malignant peritoneal mesothelioma. Arch Pathol Lab Med 130: 1654-1661, 2006.

14. Liu S, Staats $P$, Lee $M$, et al. Diffuse mesothelioma of the peritoneum: correlation between histological and clinical parameters and survival in 73 patients. Pathology 46: 604-609, 2014

15. Tudor EC, Chua TC, Liauw W, et al. Risk factors and clinicopathological study of prognostic factors in the peritoneal mesothelioma. Am Surg 76: 400-405, 2010.

16. Yan TD, Haveric N, Carmignani CP, et al. Computed tomographic characterization of malignant peritoneal mesothelioma. Tumori 91: 394-400, 2005.

17. Claimon A, Bang Jl, Cheon GJ, et al. Malignant Peritoneal Mesothelioma Masquerades as Peritoneal Metastasis on (18) F-FDG PET/CT Scans; a Rare Diagnosis that Should Not Be Missed. Nucl Med Mol Imaging 49: 325-328, 2015.

18. Low RN, Barone RM. Combined diffusion-weighted and gadolinium-enhanced MRI can accurately predict the peritoneal cancer index preoperatively in patients being considered for cytoreductive surgical procedures. Ann Surg Oncol 19: 13941401, 2012.

19. Baratti D, Kusamura S, Martinetti A, et al. Circulating CA125 in patients with peritoneal mesothelioma treated with cytoreductive surgery and intraperitoneal hyperthermic perfusion. Ann Surg Oncol 14: 500-508, 2007.

20. Oken MM, Creech RH, Tormey DC, et al. Toxicity and response criteria of the Eastern Cooperative Oncology Group. Am J Clin Oncol 5: 649-655, 1982.

21. Jacquet $P$, Sugarbaker $P H$. Clinical research methodologies in diagnosis and staging of patients with peritoneal carcinomatosis. Cancer Treat Res 82:359-374, 1996. 
22. Younan R, Kusamura S, Baratti D, et al. Morbidity, toxicity, and mortality classification systems in the local regional treatment of peritoneal surface malignancy. J Surg Oncol 98: 253257, 2008.

23. Eltabbakh GH, Piver MS, Hempling RE, et al. Clinical picture, response to therapy, and survival of women with diffuse malignant peritoneal mesothelioma. J Surg Oncol 70: 6-12, 1999.

24. Yano H, Moran BJ, Cecil TD, et al. Cytoreductive surgery and intraperitoneal chemotherapy for peritoneal mesothelioma. Eur J Surg Oncol 35: 980-985, 2009.

25. Chua TC, Yan TD, Morris DL. Outcomes of cytoreductive surgery and hyperthermic intraperitoneal chemotherapy for peritoneal mesothelioma: the Australian experience. J Surg Oncol 99: 109-113, 2009.

26. Blackham $\mathrm{AU}$, Shen $\mathrm{P}$, Stewart JH, et al. Cytoreductive surgery with intraperitoneal hyperthermic chemotherapy for malignant peritoneal mesothelioma: mitomycin versus cisplatin. Ann Surg Oncol 17: 2720-2727, 2010.

27. Sebbag G, Yan H, Shmookler BM, et al. Results of treatment of 33 patients with peritoneal mesothelioma. $\mathrm{Br} \mathrm{J}$ Surg 87 : 1587-1593, 2000.

28. Feldman AL, Libutti SK, Pingpank JF, et al. Analysis of factors associated with outcome in patients with malignant peritoneal mesothelioma undergoing surgical debulking and intraperitoneal chemotherapy. J Clin Oncol 21: 4560-4567, 2003

29. Yan TD, Deraco M, Baratti D, et al. Cytoreductive surgery and hyperthermic intraperitoneal chemotherapy for malignant peritoneal mesothelioma: multi-institutional experience. J Clin Oncol 27: 6237-6242, 2009.

30. Alexander HR, Bartlett DL, Pingpank JF, et al. Treatment factors associated with long-term survival after cytoreductive surgery and regional chemotherapy for patients with malignant peritoneal mesothelioma. Surgery 153: 779-786, 2013.

31. Miura JT, Johnston FM, Gamblin TC, et al. Current trends in the management of malignant peritoneal mesothelioma. Ann Surg Oncol 21: 3947-3953, 2014.

32. Helm JH, Miura JT, Glenn JA, et al. Cytoreductive surgery and hyperthermic intraperitoneal chemotherapy for malignant peritoneal mesothelioma: a systematic review and meta-analysis. Ann Surg Oncol 22: 1686-1693, 2015.
33. Metintas S, Metintas M, Ucgun I, et al. Malignant mesothelioma due to environmental exposure to asbestos: follow-up of a Turkish cohort living in a rural area. Chest 122: 2224-2229, 2002

34. Roushdy-Hammady I, Siegel J, Emri S, et al. Genetic-susceptibility factor and malignant mesothelioma in the Cappadocian region of Turkey. Lancet 357: 444-445, 2001.

35. Kaya H, Sezgi C, Tanrikulu AC, et al. Prognostic factors influencing survival in 35 patients with malignant peritoneal mesothelioma. Neoplasma 61: 433-438, 2014.

36. Deraco M, Bartlett D, Kusamura S, et al. Consensus statement on peritoneal mesothelioma. J Surg Oncol 98: 268-272, 2008.

37. Mirarabshahii P, Pillai K, Chua TC et al. Diffuse malignant peritoneal mesothelioma--an update on treatment. Cancer Treat Rev 38: 605-612, 2012.

38. Calabro L, Morra A, Fonsatti E, et al. Tremelimumab for patients with chemotherapy-resistant advanced malignant mesothelioma: an open-label, single-arm, phase 2 trial. Lancet Oncol 14: 1104-1111, 2013.

39. Varghese S, Chen Z, Bartlett DL, et al. Activation of the phosphoinositide-3-kinase and mammalian target of rapamycin signaling pathways are associated with shortened survival in patients with malignant peritoneal mesothelioma. Cancer 117: 361-371, 2011.

\section{Correspondence:}

Dr. Hanifi ŞAHIN

Zekai Tahir Burak Kadın Saglıgı Egitim ve

Arastırma Hastanesi

Jinekolojik Onkoloji Kliniği

Talatpaşa Bulvarı

06230 Altındag, ANKARA / TURKEY

Tel: $\quad(+90-506) 5341612$

Fax: (+90-312) 3214931

e-mail: hanifi.81_@hotmail.com 